\title{
THE INFLUENCE OF ROBOT DANBO MEDIA ON THE MATHEMATIC REPRESENTATION ABILITY OF PRIMARY SCHOOLS
}

\author{
Hani Handayani ${ }^{{ }^{*}}$ \\ ${ }^{1}$ PGSD, STKIP Sebelas April Sumedang, Indonesia \\ Corresponding*Hanihandayani.han26@gmail.com \\ DOI: https://doi.org/10.21107/widyagogik.v8i1.8653
}

Received September 9, 2020; Revised September 18, 2020; Accepted October 14,2020

\begin{abstract}
The background of the problem in this study is the low mathematical representation ability of class $V$ students. The media used to improve students' mathematical representation abilities is using the robot danbo media. volume of cubes and blocks in grade $V$ students. This study aims to determine the effect of using danbo robot media on the mathematical representation ability of class $V$ students in learning the volume of cubes and blocks in class $V$. The research method used is the one group pretest-posttest design method (one group pretest-posttest design) in Class $V$ students. This research data was collected through the pretest and posttest scores of mathematical representation abilities with a total of 6 students, after being treated using the robot danbo media. The ability of students' initial understanding before treatment (pretest) obtained an average value of 65.3 while after treatment (posttest) was 86.1. It can be seen from the results of data processing using the $t$ test with a confidence level of $95 \%(\alpha$ $=0.05$ ). It can be seen that the tcount is 3.4 and the ttable is 2.5706. So that $H_{-} O$ is rejected, meaning that there is an effect of using danbo robot danbo media on the mathematical representation ability of the volume of blocks and cubes in class $V$.
\end{abstract}

Keywords - Robot danbo media, mathematical representation ability.

(C) 2020 Elementary School Teacher Education Departement, Faculty of Education, Universitas Trunojoyo Madura 


\section{Introduction}

Mathematics is a basic science that has an important role in the development of science. Mathematics is a science of education that has a function in developing the ability to calculate, measure, determine, and use mathematical formulas to deal with problems related to mathematics in everyday life. The objectives expected in learning mathematics by the National Council Of Teachers Of Mathematics (2002: 52) apply five standard abilities that students must have, namely, "Problem solving skills, communication skills, connection skills. , the ability to reason (reasoning), the ability to represent (representation) ". The ability of mathematical representation is one of the general goals of learning mathematics in schools. According to Handayani (2019: 49) the ability of representation, namely, the ability of students to solve math problems. The ideas issued by students consist of visual representations, representations of mathematical equations or expressions, and representations of words or written texts. In learning mathematics representation has a very important role. The ability of representation can help students to understand knowledge and solve mathematical problems.

This is in line with the opinion of Sabirin (2014: 35) which states that, "Representation plays a very important role in developing and optimizing students' mathematical abilities". Kartini also argues (2009: 361) that, "Representation plays a role in helping understand concepts, communicating and solving problems". In line with this opinion, NCTM (Sabirin, 2014: 34) states, "Representation is a way a person uses to communicate the answer or mathematical idea concerned". Based on the opinion of experts, it can be concluded that in solving mathematical problems students must have the ability of mathematical representation, where the representation is a mathematical expression or idea displayed by students as a substitute for a problem situation that is used to find a solution to the problem at hand which is the result. interpretation of his thoughts through verbal, visual and symbolic. In reality on the ground, the ability to represent representation is less developed in learning.

Based on the results of observations in one of the classes at the grade $V$ level in Sumedang, the percentage of students' mathematical representation scores was 29 people and KKM 75 on the visual representation indicator was $20.67 \%$, verbal $60.99 \%$, and symbolic representation $41.99 \%$. From the whole, the average representation of students in the school is $41.21 \%$. In addition, in research conducted by Handayani and Juanda (2018: 214) by providing problem-solving test questions to measure the ability of mathematical representation, there is the fact that, "The ability of elementary school students' mathematical representation in Sumedang Regency only reaches $24.9 \%$ with a very low category. . For the verbal representation ability was $30.3 \%$, the symbolic representation ability was $25.2 \%$ and the visual representation ability was $19.3 \%$ ". In general, it can be seen that the mathematical representation ability of students is still low. From these facts, it is revealed that students in Indonesia are still weak in their mathematical representation skills. Given the importance of mathematical representation skills for students, teachers are required to be able to package learning 
more fun. In learning mathematics, not only the learning model is used but learning media also needs to be given to students to build their own knowledge. Therefore, suitable media is needed in learning mathematics. Researchers try to provide alternative solutions to deal with the problems faced by students in understanding the volume material of cuboid cubes by applying the use of robot danbo media. Robot danbo media is a learning medium that can be used in mathematics learning, especially in the material for the volume of cubes and blocks. The robot danbo media resembles a danbo doll. Danbo is short for danboard, made from cardboard board (cardboard). This doll is the creation of Azuma Kiyohiko, a comic artist for the Yotsuba manga series. This doll is very unique, namely an action figure with a human-like appearance. Danbo is very popular because danbo can be moved hands, head and feet so that it can be formed with a variety of unique styles. The danbo robot form as shown below.

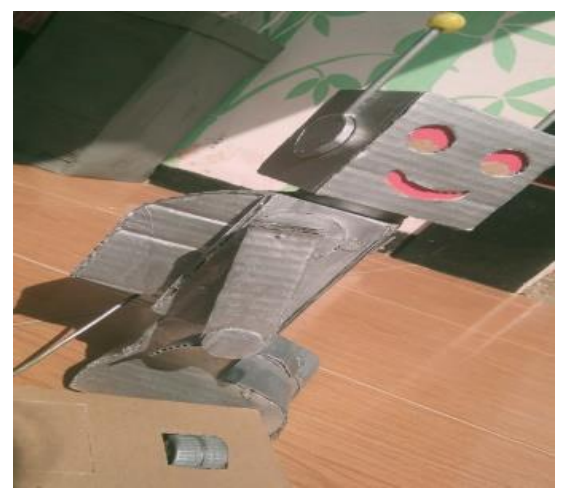

Figure 1. Media Robot Danbo

So seen from the uniqueness of this danbo doll, the researcher intends to try to do research using danbo as a learning aid. The difference is that the researchers designed the danbo doll not as usual (in the form of blocks only) but from several structures such as cubes and blocks. In addition, this media can move using a remote control, its shape will be slightly different, namely like a robot, so the researchers named this learning media robot danbo block cubes. Apart from being used as a learning medium as well as an interesting educational game, it can foster students' mathematical representation abilities as well as make the learning process more enjoyable. Based on the description above, the researcher is interested in conducting research on the use of danbo robot media in mathematics learning material volume cube and block volume. Therefore, the author embodies in the form of research with the title "The Effect of Using Robot Danbo Media on the Ability of Mathematical Representation".

\section{Method}

The method used in this study used pre-experimental designs or pre-experimental methods. According to Sugiyono (2007: 109), "it is said to be pre-experimental designs, because this design is not a serious experiment because there are still external variables that influence the formation of the dependent variable". In other words, the pre- 
11 The Influence Of Robot Danbo Media On The Mathematic Representation Ability Of Primary Schools

Hani Handayani

experimental method results from the independent variables. This can happen, because there is no control variable and the sample is not randomly selected. The research design used in this study was a pre-experimental method using the One Group PretestPosttest Design. One-Group Pretest-Posttest Design is a study that conducts a pretest before being given treatment. Thus the treatment results can be found to be more accurate, because they can be compared with the circumstances before being treated. According to Sugiyono (2017: 74), this design can be described as follows.

$$
\mathrm{O}_{1} \times \mathrm{O}_{2}
$$

Figure 2. Pre-experimental One Group Pretest-Posttest Design Formulas

Information :

$\mathrm{O} 1=$ pretest value (before being given treatment) .

$X=$ Treatment using robot danbo media

$\mathrm{O} 2$ = Posttest value (after being given treatment).

The sample used in this study were 6 grade $V$ elementary school students in the village of Cibenda, Sumedang. The technique data collection used was the mathematical representation ability test technique in the form of 3 description questions. The data analysis technique is through the data normality test through the Liliefors test, if the data is normally distributed, then it is followed by the $t$ test to see whether or not the robot danbo media influence the students' mathematical representation ability.

\section{Result and Discussion}

The learning process is carried out by means of a home visit which is divided into two groups which are carried out in different places. The pretest research data is taken from the test results given before the implementation of learning on the volume of cubes and blocks using the robot danbo media, and the posttest data is taken from the test results given after the implementation of learning on the volume of cubes and blocks using the robot danbo media. Based on the results of data analysis on the normality test using the Liliefors test, the results are according to the table below.

Table 1. Normality Test Results ( $\alpha=5 \%)$

Lilliefors test result

\begin{tabular}{|c|c|c|c|c|c|c|}
\hline Class & $\mathrm{N}$ & $\bar{X}$ & $\mathrm{~S}$ & $L_{\text {count }}$ & $L_{\text {table }}$ & Information \\
\hline Pretest & 6 & 65,3 & 18,28 & 0,1915 & 0.3190 & $H_{0}$ is accepted \\
\hline Posttest & 6 & 86 & 10,18 & 0,2154 & 0.3190 & $H_{0}$ is accepted \\
\hline
\end{tabular}


From table .1 it can be seen that $L_{\text {hitung }}$ for the initial test is 0.1915 whereas $L_{\text {table }}=0.3190$. his means $L_{\text {count }}<L_{\text {table }}$ meaning that $H_{0}$ is accepted. And, in the final test $L_{\text {count }}$ is $0.2154 L_{\text {table }}$ and is 0.3190 then $L_{\text {count }}<L_{\text {table }}$ meaning that $H_{0}$ is accepted. So the initial test (pretest) and final test (posttest) are normally distributed. Then proceed with the $t$ test to test the hypothesis.The pair of hypotheses used are as follows.

$H_{0}$ : There is no effect of using robot danbo media on the mathematical representation ability of the volume of cubes and the volume of blocks.

$H_{1}$ : There is an effect of using robot danbo media on the mathematical representation ability of the volume cube and block volume material.

Test criteria: If $;-t_{\text {table }} \leq t_{\text {count }} \leq t_{\text {table }}$ then $H_{0}$ is accepted

$$
\text { If: }-t_{\text {table }} \geq t_{\text {count }} \geq t_{\text {table }} \text { then } H_{1} \text { rejected }
$$

From the calculation of $\mathrm{t}$ count and $\mathrm{t}$ table with a significance level of $5 \%$ as shown in Table 2.

Table 2. T test result $(\alpha=5 \%)$

\begin{tabular}{|c|c|c|c|c|c|c|}
\hline Class & $\mathrm{N}$ & $\bar{d}$ & $\mathrm{Sd}$ & $t_{\text {count }}$ & $t_{\text {table }}$ & information \\
\cline { 1 - 6 } Pretest & 6 & \multirow{2}{*}{20,8} & 14,71 & 3,4 & 2,5706 & $H_{0}$ rejected \\
\cline { 1 - 2 } Posttest & 6 & & & & & \\
\hline
\end{tabular}

From table 2 , the value of $t_{\text {count }}=3,4$ is outside the receiving area of $H_{0}$, then $H_{0}$ is rejected and $H_{1}$ is accepted, so the conclusion is that there is a significant effect of using robot danbo media on the mathematical representation ability of the material of block volume and cube volume. Based on the research results, it was obtained the results of data analysis and hypothesis testing. From the results of data processing, it is known that the overall pretest score of students obtained the lowest score of 44 , the highest score of 87 and the average value $(\bar{X})$ of 65.3. After being given the treatment, it is known that the posttest scores on learning mathematics material volume cubes and blocks using the danbo robot media in class $V$ as a whole get the lowest score of 75 , the highest value of 100 and the average value of $(\bar{X})$ 86.1. Based on the normality test with calculations using the Lilliefors test, the initial test (pretest) obtained $L_{\text {count }}=0.1915$ and $L_{\text {table }}=$ 0.3190 . While the final test (posttest) obtained $L_{\text {count }}=0.2154$ and $L_{\text {table }}=0.3190$. This means that $L_{\text {count }}<L_{\text {table }}$, thus $H_{0}$ is accepted, then the pretest and posttest results are normally distributed. From the results of data processing using the $t$ test, it can be seen that the value of $t_{\text {count }}=3.4$ and $t_{\text {table }}=2.5706$. So that $H_{0}$ is rejected, meaning that 
13 The Influence Of Robot Danbo Media On The Mathematic Representation Ability Of Primary Schools

Hani Handayani

there is an effect of using the robot danbo media on the mathematical representation ability of the volume cube and block volume material.

By using the robot danbo media in learning cube volume and block volume to become more interesting, students become more familiar with the learning material. In accordance with the opinion of Sudjana and Riva'i (Kustandi and Sutjipto, 2016: 22) there are four benefits of learning media in the student teaching and learning process as follows. 1. Learning will attract more students' attention, so that it can foster learning motivation. 2 Learning materials will have a clearer meaning so that students can better understand them and allow them to master and achieve learning goals. 3. Teaching methods will be more varied, not solely verbal communication through wording by the teacher, so that students do not get bored and teachers do not run out of energy, especially if the teacher teaches during every lesson. 4. Students can do more activities because they don't only listen to the teacher's description, but also other activities, such as observing, doing, demonstrating, acting out, and so on. This is also in accordance with the opinion according to Sadiman (Kustandi and Sujipto, 2016: 7) that, "Media is an intermediary for delivering messages from sender to message recipient". More specifically, the notion of media in teaching and learning is defined as the teaching and learning process which tends to be graphic, photographic, or electronic tools to capture, process, and reconstruct visual or verbal information. Learning the volume of cubes and blocks using the robot danbo media makes students very enthusiastic in manipulating the media of the racing bus wheels, students are actively involved in finding the volume of the robot danbo, so this has led to improving students' mathematical representation abilities.

The advantages of this media are that it makes it easier for students to learn and understand the volume of cubes and blocks, in addition, this media can be used for several lessons because it is made of durable materials. Referring to the explanation of the learning media above, the robot danbo media is expected to help students understand the volume of cubes and blocks because the racing bus wheel media is a concrete object and can be used by teachers and students directly and its use is very easy. It can be concluded that although the learning process has various obstacles due to Covid-19 so that it cannot be carried out optimally according to plan, the danbo puppet media can have a significant effect on the mathematical representation abilities of elementary school students.

\section{Conclusion}

There is an effect of using danbo robot media on the mathematical representation ability of class $V$ students in learning the volume of cubes and blocks with the overall pretest score of students obtaining an average score of $(\bar{X}) 65.3$. After being given the 
treatment, it is known that the posttest results in mathematics learning material volume of cubes and blocks using robot danbo media in class $V$ as a whole get an average value of $(\bar{X})$ 86.1.

Author Contributions: The author's contribution in this study is a researcher, data collector, and data analysis.

Funding: This research was funded by Kementerian Riset dan Teknologi/Badan Riset dan Inovasi Nasional Deputi Bidang Penguatan Riset dan Pengembangan Kementerian Riset dan Teknologi/Badan Riset dan Inovasi Nasional 2020, Nomor 8/E1/KPT/2020

Acknowledgments: First of all I would like to thank the UPT research who has guided the author so that he gets a research grant for the 2020 funding year, I also thank the Ministry of Research and Technology, the Deputy for Research and Development of the Ministry of Research and Technology who has funded this research so that research this can be done smoothly to the end.

Declaration of Conflicting Interests: "The authors declare no conflict of interest", anda "The funders had no role in the design of the study; in the collection, analyses, or interpretation of data; in the writing of the manuscript, or in the decision to publish the results". 
15 The Influence Of Robot Danbo Media On The Mathematic Representation Ability Of Primary Schools

Hani Handayani

\section{References}

Handayani, H dan Juanda, R. Y. (2018). Profil Kemampuan Representasi Matematis Siswa Sekolah Dasar Di Kecamatan Sumedang Utara. Kemampuan Representasi Matematis, 7, (2), 443-448.

Handayani, H. (2019). Analisis Kemampuan Representasi Siswa Pada Materi Volume Kubus Dan Balok Di Sekolah Dasar. Jurnal of Madrasah Madrasah Ibtidiyah Education, 3, (1), 48-61. DOI: http://dx.doi.org/10.32934/imie.v3i1.97

Kartini. (2009). Peranan Representasi Dalam Pembelajaran Matematika dan Pendidikan Matematika Jurusan Pendidikan Matematika. Yogyakarta: FMIPA UNY.

Kustandi, C. dan Sutjipto B. (2016). Media Pembelajaran; Manual dan Digital. Bogor: Penerbit Ghalia Indonesia.

NCTM. (2002). Principles and Standards for School Mathematic. Reston, VA: NCTM.

Sabirin, M. (2014). Representasi Dalam Pembelajaran Matematika. JPM IAIN Antasari, 01, (2), 33-34. DOI: http://dx.doi.org/10.18592/ipm.v1i2.49.

Sugiyono. (2007). Metode Penelitian Pendidikan Pendekatan Kuantitatif, Kualitatif, dan $R \& D$. Bandung: Alfabeta.

C 2020 by the authors. Submitted for possible open access publication under the terms and conditions of the Creative Commons Attribution ShareAlike (CC BY SA) license (https://creativecommons.org/licenses/by-sa/4.0/). 